\title{
WILDLIFE MANAGEMENT IN RELATION TO MULTIPLE USE IN EASTERN CANADA ${ }^{1}$
}

\author{
By C. H. D. CLARKE ${ }^{2}$
}

So far as wildlife is concerned, multiple use, whether in respect to forest lands or agricultural lands, is a term that describes what has existed since the land became used for forestry or agriculture. It is not something that we might plan to put into effect in the future. Wildlife resources are found on all our lands, and wildlife management is an integral part of land use everywhere. What is needed is for it to become an integrated part of land use.

To illustrate the universal presence of wildlife resources it may be stated that trapping of fur-bearing animals is still carried on extensively within the limits of the City of Toronto. The cash-yield per acre per year at present, taking into account the whole acreage of the city, including brick and asphalt, is at a rough estimate, between two and three cents, which is quite comparable to the yield of a wilderness area in the far north. On Pelee Island in Lake Erie, comprising some of the most productive and most valuable agricultural land in Ontario, the revenue derived by the municipality and residents from the 1950 pheasant shoot was about $\$ 10$ per acre. The total yield was higher. There is multiple use with a vengeance, - a maximum yield from both wildlife management and agriculture on the same acres, with a minimum of interference of one with the other.

Over a vast area of Canada, well over one-half of the total, wildlife management is the only form of land use practised or likely to be practised, and forests are important only as a home for wildlife. Where the potential wildlife yield is high, forest protection is justified on that account alone. However, wildlife values on such lands are lower than on those where forestry and agriculture are the primary land use.

Neither wildlife itself, nor its use for commerce or recreation can be excluded from our forest and agricultural land. Such being the case, the single use of land is impossible. As multiple use is the only kind of use we are ever going to have, we are wasting our resources if we do not manage for maximum over-all yield.

Leopold (Game Management, N.Y. 1947) classifies wildlife (which we can conveniently use where he says "game"), as Wilderness Game, Forest and Range Game, Farm Game and Migratory Game. Wilderness Game, such as musk-ox, mountain sheep and grizzly bear, are species intolerant of disturbance, characteristic of those areas where wildlife management is the basic land use. Forest Game are species characteristic of areas where forestry is the basic land use - principally deer and some grouse. Leopold includes moose with Wilderness Game, but our experience does not support him, and after a look at Sweden, with its kill of 15,000 moose a year, we place them unhesitatingly in Forest Game. Farm Game includes the species on agricultural land,

\footnotetext{
1 Presenter at the annual meeting of The Canadian Institute of Forestry, Banff. Alberta, October 11-13, 1951.

- Ontario Department of Lands and Foresta, Toronto, Ontaria.
} 
and Migratory Game crosses all classifications. To a surprising degree the types are exclusive, and the classification must be considered as following natural lines of land use.

As we cannot reasonably talk about whether or not we should have multiple use, or how to get multiple use, there remains only the question of whether we are getting a high over-all yield, and if not, how should we go about it.

Looking first at wildlife management in its relationship with forestry, we have to deal with three different major subdivisions in space. First we have the large area of public land beyond the limits of commercial forestry. The next division is the large area of public land wholly or partially under management with forestry the basic land use. The last division is privatelyowned land, on some of which forestry is a primary consideration, but on most of which agriculture is the basic land use.

In the hinterland beyond commercial forestry, the basic administrative organization is generally concerned also with other resources, and frequently with the forest resources, of the more accessible lands. So long as this does not amount to a preoccupation that excludes active management of the primary wildlife area, there is no conflict with forestry. Wildlife management in such areas should pay for itself many times over. The active management of the wildlife of the Patricia District of Ontario pays for itself many times over in the increase of royalties and licences, not even considering the value to the commerce of the country of the wealth produced, or the fact that a large and increasing Indian population is maintained on a self-supporting basis. After all, that area is now in the stage that marked the beginning of the economy of most parts of Canada, where all began with the fur trade. The addition of some new element such as mining, logging, tourism, or commercial fishing is simpler where there already exists population, trade and transportation based on fur management. Thereafter each element can lend strength to the other in a development that should be on a sustained yield basis for all living resources involved.

Within the area of forest management we really need only to refer to an excellent paper by de Vos (Sylva 1949, Vol. 5 pp. 29-34), in which it is made clear that basically sound forest management is good for wildlife. We can develop this still further by saying that, on the available evidence, where wildlife management and forest management seem to be in conflict, the premises, objectives and methods of both should at once be critically examined, because it is altogether likely that one or both sides is in the wrong, in terms of the greatest ultimate good to all. He points out that the interspersion of cover types required by wildlife can be provided easily in any system of forest management. In areas burned or indiscriminately slashed, wildlife cover is deficient. Fire, under control, we can see, has a potential place in both wildlife and forest management.

It would be a great deal easier to talk about bringing forest and wildlife management into line with each other if we were a little closer to the practice of silviculture in Canada. Where have we a large forest of any degree of development whose existence and present composition is the result of manage- 
ment? Forest crops have a long turnover. The life cycle of a Scotch pine Christmas tree operation is longer than any accurately established wildlife population turnover. The well known grouse and rabbit cycles make a complete round in ten years. There are hints of longer cycles in larger animals but they remain unproven. The repopulating of game cover is very fast compared to the growth period of a stand of saw-logs. Wildlife management should, therefore, be basically easier to accomplish than forest management and may antedate silviculture to the extent that the two can exist separately. In such a case it will surely help bring siliviculture into existence.

Unmanaged wildlife populations can effectively block silviculture, as de Vos has pointed out. O'Roke and Hamerstrom (Jour. Wildl. Man. V. 12, pp. 78-86, 1948) have shown that white-tailed deer can increase from six to one-hundred and sixty in six years. Without a proper harvest they can destroy the forest regeneration over great areas. Without public support for a proper harvest, both wildlife biologists and foresters have had to sit back and watch range destruction on a state-wide scale. Both resources suffer in the end. There are enough similar instances in other species that no one need feel surprised at learning of a case where bad wildlife management has damaged the forest. It should be equally obvious that the reverse must be true.

Anyone looking for a clear picture of the way in which forestry and game management may have to work together is referred to Grange's "Wisconsin Grouse Problems" (Wisconsin Cons. Dept. n.d.). The various species of grouse are characteristic of various successional stages in the development of the forest. If all the forests pass through all the stages at once, as they do after large fires, the recreational use pitches from boom to depression.

Large private forest holdings are not very different from public lands insofar as management practices across the country are concerned, but there is a basic difference that cannot be ignored. On public lands the Crown retains an interest in the forest and full proprietorship of wildlife. Management of either is something that is imposed from above, but the exploiter of the resources, whether lumberman or trapper, cooperates much better when he can see himself as the beneficiary of his efforts. Modern trap-line management of fur-bearing animals consists in giving the trapper as great a degree of proprietorship in the resource as the circumstances permit. Wildlife management on large private forest holdings, i.e. private lands on which forestry is the dominant land use, is more likely to follow the pattern of either Crown lands or farm lands than to set a new pattern of its own.

On most of the private lands in the country agriculture is the dominant land use and both forestry and wildlife management are secondary. Both should mesh smoothly with the prevailing farm economy and with each other as well. Wildlife is, however, produced just as much on the cropland as on the woodland. No other game crop can match farm game crops in ultimate value, because of their volume of recreational use.

Large crops of farm game are produced only on rich soils (Allen, 1950, Jour. Wildl. Man. V: 14, No. 2 p. 110). The general problem of maintaining and building up soil fettility and building up farm wildlife is one and the same. Faulkner (Ploughman's Folly, N. Y. 1943) has remarked that 
soil types as we now know them were once masked by a coating of organic material over all. Some soil specialists don't agree with his statement, but, forgetting such bits of history as the preference of the Loyalist settlers for what are now the Long Point sand dunes, I cannot help noting that Woodcock were shot in the fields throughout the early history of Ontario. That includes fields that are now sand dunes and fields that are hard baked clay in fall. Woodcock are not found in Ontario fields now and have not been since Confederation, but one can imagine how rich and easily worked those fields once were. This land is still good, but it has lost an extra degree of fecundity, reflected in the fact that woodcock find probing unproductive or impossible. On the agricultural side we make up for it by using fertilizers, but the pioneers had less trouble with pests and blights and one can well believe that their farm products were superior, other things being equal. Wildlife is a good indicator for crop-land management. It shows the effect of soil deterioration, while crops are still flourishing, and on the other hand it responds with gratifying rapidity to any basic improvement of the soil. Why do waterfowl swarm in the nesting season on the bare shores of some western sloughs while they are absent from comparable eastern areas with rich cover? Why are the marshes of the pre-Cambrian shield so unproductive? The case for fertility is clear.

If, basically, what is good for the land is good for wildlife, as we have seen in this case, then we are in the same position as regards the coexistence of agriculture and wildlife management on the same ground as we were with forestry. Where conflict of interest exists we can expect to find unsound soil management, unsound wildlife management or both. If we find ourselves questioning the basic soundness of superficially sound and accepted farm practices let us not be surprised. Wildlife biologists are often forced by diplomacy to prescribe palliatives to increase farm game where a change in regimen would be more in order. The farm that is being run now so that the farmer's descendants may still be making a good living on it in another millenium will have plenty of game on it. Before we subscribe to the belief that in another millenium twenty billion people will be on the earth nourished by capsules of concentrates let us remember that centuries of technical advances have not changed anything basic about our renewable resources except the rate of exploitation.

Both wildlife management and forestry on the farm could get along famously on the minimum that sound farm management would give them (c.f. Graham, "Natural Principles of Land Uses," N.Y., 1944). However, a maximum wildlife crop requires a little extra consideration, which is the order of the day in Europe but rare enough here. Of two fertilizers identical so far as plant growth is concerned, one is better for the production of the harmless insects on which young partridges feed (c.f. I.C.I. Game Researches, Advisory Leaflet No. 7, Jan. 1935). In Britain the same company makes fertilizers and cartridges, and is able to swing the balance in favour of the partridges. The game manager's needs for coverts, breaks and flushing points, as well as belts of tall trees to make the driven bird fly high and fast, combines perfectly with the farm need for fuel, and produces poles, props and sawlogs as well. The hedges needed (and paid for) by the local hunt are 
runways for game and breeding places for a host of smaller creatures that benefit crops. Recent research shows clearly that brush, shrub and hedge field borders harbour fewer crop pests (Dambach, in Ohio State Un. Grad. School Studies, Biol. Series No. 2 1948) whereas turf shelters pests in quantity, from field mice down. At present field border cover, often the only worthwhile wildlife cover left, is being destroyed at an accelerated rate, by highway and municipal road engineers and clean-farming fanatics. Clean farming, the goal of a century of misguided agriculture, is now within reach, thanks to chemistry, just at the time when the true significance of weeds as nature's agents in a vain struggle to maintain the fertility of the soil against man's constant depletion is becoming understood (c.f. "Weeds: Guardians of the Soil" by Joseph A. Cocannouer.)

In all such special consideration for wildlife we face the fact that, whereas fields and forests belong to the farmer, the game belongs to the Crown. Traditionally, its pursuit on both public and private lands is free. Why should any farmer go beyond the needs of good soil management to provide game for the public? There are enough gun-goons abroad today that game on the farm can be a liability. Anyone with a little imagination can see that free shooting is a myth. There are few more expensive sports today, and it is ridiculous to expect no expenses at the production end. Farmers are beginning to realize that although they do not own the game there can be no access to it without trespass, and sportsmen begin to see that they must meet the trespass problem fairly or there is no future to recreation on somebody else's land.

When everyone is reconciled there is a nice job awaiting farmers, foresters and wildlife biologists on wet woodlands in old Ontario. Foresters have solved the problem of dry woodlots very well, but they have yet to make an important contribution to management of the wet lands which are so important in maintaining streams and wells. Here the wildlife biologist can help. There is a judicious balance that can be maintained, using the cow and the axe as tools, with a forest that foresters will not like until they grasp the wildlife management implications. In it the grazing will carry the overhead, and there is a production of fuel wood, a few poles and logs, and trout, woodcock, grouse, rabbits, deer and fur-bearing animals to pay the dividends. It exists in enough places by accident, not design, to assure its success.

In all this discussion, wildlife has meant mostly the animals that are objects of the chase. We know all the while that other forms are of immense value and that there is an enormous non-exploitive use of all forms of wildlife. In a place like Banff one becomes more highly conscious of this type of wildlife value. We can, however, think in terms of game safely enough, because, as we have seen, the basis of game production is a healthy biotic community, and the biotic community includes all the plants and animals. 